\title{
THE OBLIGATORY UNDERWATER LEVEL: POSTHUMAN GENEALOGY OF AMPHIBIAN HUMAN IN MEDIA
}

\author{
Alesja Alesha Serada \\ University of Vaasa. Vaasa, Finland. Email: aserada[at]uwasa.fi
}

\begin{abstract}
Will humankind ever be able to live underwater? To answer this question from the perspective of visual media studies, I analyze narrative and expressive means used for positive representation of underwater experiences in several examples of screen media. My examples are principally different by origin and yet united by their highly enjoyable effect of immersion into underwater worlds. My primary focus is on Amphibian Man (1928), a cult early science fiction novel by Alexandr Belyaev adapted for screen in 1962 in the USSR.I also explore its unintentionally close contemporary reproduction in The Shape of Water (2016), which even led to accusations in plagiarism. The third example is a contemporary independent video game ABZU by Giant Squid (2016), which replays the same theme of amphibian human existence in a positive light. These cases present a surprisingly rare view of a safe, friendly and interactive marine world, approached by the protagonist who can breathe underwater. I apply the posthumanist lens to find out that, surprisingly, aquatic cyborgs seem to be underrated by the queer thought (Haraway, 2015, 2016); I conclude that the model of 'queer ecologies' may become the needed development.
\end{abstract}

\section{Keywords}

Soviet cinema; science fiction; blue humanities; game studies; film studies; queer ecologies; posthuman; body modifications; legal personhood; Alexander Belyaev

This work is licensed under a Creative Commons «Attribution» 4.0 International License 


\section{ОБЯЗАТЕЛЬНЫЙ ПОДВОДНЫЙ УРОВЕНЬ: ПОСТЧЕЛОВЕЧЕСКАЯ ГЕНЕАЛОГИЯ ЧЕЛОВЕКА-АМФИБИИ В МЕДИА}

\section{Серада Алеся Алеша}

Ваасский университет. Ваaса, Финляндия. Email: aserada[at]uwasa.fi

\section{Аннотация}

Сможет ли человечество в будущем переселиться в подводный мир? Чтобы ответить на этот вопрос из перспективы исследований визуальных медиа, я анализирую нарративы и выразительные средства, использованные для позитивной репрезентации опыта жизни под водой в нескольких примерах экранных медиа. Мои примеры принципиально отличаются по происхождению, но их всех объединяет необычайно приятный эффект от погружения в подводные миры. В основном я фокусируюсь на культовой повести «Человек-амфибия» (1928) - раннем примере научной фантастики Александра Беляева, который был экранизирован в СССР в 1962 году. Кроме этого, я рассматриваю предположительно случайное современное воспроизведение того же сюжета в фильме «Форма воды» (2016). Наконец, третий пример - инди-игра ABZU (2016), в которой в таком же позитивном свете воспроизводится та же самая тема существования человека под водой. Эти три случая представляют удивительно редкую картину безопасного, дружелюбного и интерактивного подводного мира, протагонист в котором способен дышать под водой. К сожалению, согласно моим выводам, перспектива постгуманизма обнаруживает поразительное отсутствие интереса к возможностям подводных киборгов, и ее следует дополнить если включить в нее “квирные” (небинарные) экологии.

\section{Ключевые слова}

Советское кино; научная фантастика; blue humanities; исследования игр; исследования кино; queer ecologies; постгуманизм; телесные модификации; законное признание человеком; Александр Беляев 


\section{INTRODUCTION}

Imagine immersing yourself into the ocean at dawn, surrounded by "...the bluish purple darkness of the deep. Fish swim by, looking light green, with dark spots and stripes. Red, yellow, lemon-colored, brown fishes constantly buzzing around like swarms of colorful butterflies”... (Belyaev, 1993, p. 48). This is just one of many dreamlike descriptions of the diving experience provided by a cult science fiction writer who, due to the common limitations of Soviet citizenship, has never been in the tropics and never went abroad since the establishment of the USSR. In the same immersive mode of appreciation, any of his colorful passages could serve as a description of the experience offered by a spectacular video game $A B Z \hat{U}$ (2016), created by an independent studio Giant Squid and recognized for its exceptional aesthetic qualities. This game, brimming with contrasting colors and filled with unnatural sources of light, remains truthfully realistic in depicting sea species, although still with a bit of imagination - not all of them coexist in the wild (PlayStation, 2016). The goal of the game is similar, in a way, to the creative mission of Amphibian Man: to present the magnificent, friendly and safe oceanic world through the eyes of a naturalized amphibian sea dweller. Our question is: if this experience is so enthralling, why don't we have more games like this?

Underwater exploration games may gain more popularity in the quickly approaching future of more available virtual reality experiences. It is already the theme of many interactive VR demo reels such as immersive experiences of theBlu series. Demand for such experiences has already been marked by earlier, highly culturally important games such as Bioshock and especially seabed scenes in Bioshock 2, experienced by players as particularly peaceful and introspective (Schott, 2016, pp. 79-80). Still, the ocean world remains underrepresented in video games, although "the obligatory underwater level" has already become a trope in mainstream gaming. Such levels are rarely relaxing or even enjoyable, which also points at a very specific set of cultural meanings attached to aquatic environments. I argue that this specific way of conceptualizing bodies of water as danger is neither default nor given, although still difficult to transcend.

In this article, I will describe a specific techno-utopian motive: artificial creation of an underwater human, first celebrated by Alexander Belyaev, internationally acknowledged as the first professional science fiction writer in the USSR (Suvin, 1979, p. 263) in one of his best-known novels Amphibian Man (1928). I will evaluate how 'humanity' of the amphibian man is defined, challenged and extended in the text and its cinematic derivatives. Did this understanding of humanity, and the peaceful utopia of coexistence with the ocean, 


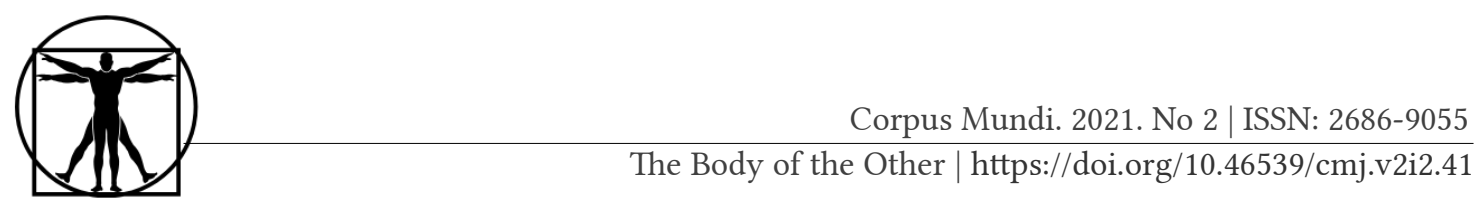

survive in the popular film adaptation of Amphibian Man? Why was it, supposedly independently, reproduced in The Shape of Water? Before answering these questions, I will turn to another reproduction of the same idea in the medium of video games, the already mentioned game $A B Z \hat{U}$.

\section{OCEANS (AND EASTERN EUROPE) AS TERRA INCOGNITA}

Humankind has formed special bonds with seas and oceans in its earliest history and allegedly, even before history, as the much criticized, and in itself rather fantastic, aquatic ape hypothesis suggests (Foley \& Lahr, 2014). Throughout the 20th century, these relationships were mostly exploitative, which required additional measures to protect aquatic ecosystems, even though the general public habitually saw it differently in the media, especially in the films made in the USA. As Stacy Alaimo writes, when we watch creature features such as faws, "we find that humans, despite the overwhelming evidence to the contrary, are the endangered species" (Alaimo, 2001, p. 279).

Ocean is commonly presented as a menace in American film and TV. The faws series registered the peak of this kind of anxiety, embodying the dangerous unknown from the deep blue, eventually angered by perpetual human trolling. It is curious, however, to see how this narrative incorporates Japanese sea monsters that initially embodied anxiety caused by the military threat coming from the USA. Pacific Rim (2013) represents one of the most noticeable and loud American ancestors from another long bloodline of 'kaiju' films, inspired by both traditional and contemporary Japanese imaginary as well as the horrors of global politics. Bodies of water are rarely framed as a threat in the Japanese culture, even despite spawning some of the best known oceanic monsters in science fiction.

Historically, European cultures have offered many alternative, even if troubled, perspectives of coexistence with the sea, with most compelling narratives coming from its seaside periphery. It is of great importance to keep in mind that this 'periphery' used to be the most productive source of signs and meanings that constitute what we now call European culture, in compliance with the theory of 'semiosphere' proposed by the Russian structuralist Yuri Lotman (Lotman, 2001). Giant (or maybe just average, for their time) squids look at us from decorated 3,500 year old vases found on Crete that belonged to the advanced Minoan civilization. Its history inspired the classical Greek mythology and probably the story of Atlantis, which continued its existence underwater in many works of speculative fiction (including $A B Z \hat{U}$ ). Curiously, Donna Haraway eagerly borrows a Eurasian Sumerian goddess as a symbol of her chthulucene project but chooses not to acknowledge 
the oceanic genealogy of the chthonic Medusa, deliberately dragging her back into the earthly mud (Haraway, 2016).

Classical antiquity became an ocean bed for many later developments of supernatural waterside romance. The many daughters of Poseidon would not shy away from an affair with an earthborn human. Other local mythologies have cultivated an international assembly of pre-Disney mermaids and mermen (both marine and freshwater). Queer inspiration stiffened by Protestant ethics lurks in the original mermaid of H.C.Andersen, while magical thinking still engenders numerous and mischievous 'rusalki' in the rivers of Eastern Europe (and in The Witcher). On yet another extremity of historical Europe, there used to be yet another way to conceptualize coexistence and possibly hybridization between humans and sentient sea creatures, called selkie, later recreated, for example, in the Irish-based film The Secret of Roan Inish (1994). This heartwarming, even if deeply saddening, perspective is radically different from the underwater nonhuman horror of the settlers' America in The Shadow over Innsmouth (1936) by H.P.Lovecraft.

With so much material to work with, we will start from the former Eastern bloc. There are, at least, two keystone works that feature sentient amphibian subjects whose humanity is questioned, although in different ways: Amphibian Man by Alexander Belyaev in the USSR and The War with the Newts by Karel Čapek in Czechoslovakia. Both novels enjoyed immense popularity, originally and in translation, on the 'wrong' side of the Iron Curtain, but only Amphibian Man received a memorable film adaptation, so influential throughout decades that it brought accusations of plagiarism on the producers of The Shape of Water (2017).

\section{THE STORY AND THE HISTORY OF AMPHIBIAN MAN}

Alexander Belyaev was born and spent his youth in Smolensk, a borderline city between ethnic Russian and Belarusian territories, later in Russia within the Soviet Union. Due to Pott disease, Belyaev was disabled for several prolonged periods of his life, which ended under the Fascist occupation near Saint Petersburg: being immobile, the writer literally froze to death. In his better times, he was a wildly productive author with a joyfully utopian, optimistic perspective. This optimism happened to suit the Soviet literature even in the times of Stalinism, which Belyaev witnessed at their darkest. The author pays his dues to the regime in some of his fictional worlds, but, in the contemporary context of disillusion with capitalism, they still hold up as rather crafty fully automated space communist utopias (see Star KETs for an example).

As Belyaev admitted himself (Kravklis \& Levitin, 2009), bodily constraints inspired some of his uncannier fantasies, such as severed heads kept alive 


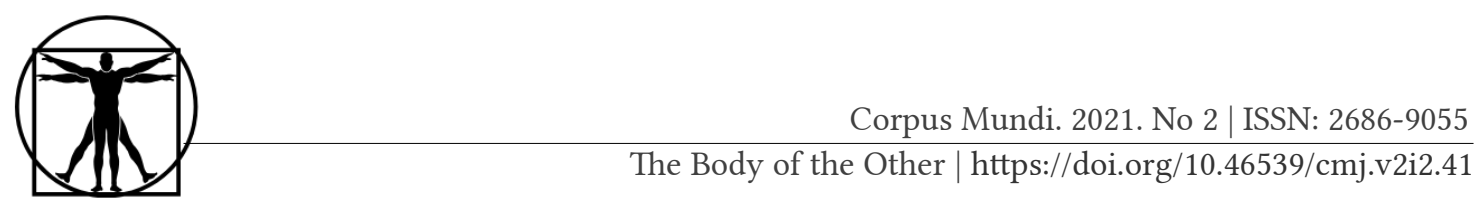

(Professor Dowell's Head (1925)). Cyborg-like creatures are also regularly present: for instance, sentient dogs with human arms in Star KETs and, most prominently, Ichtiandr, the main character of Amphibian Man. He is a young and handsome shark-man cyborg who supposedly lives on the ocean floor near Buenos Aires, Argentina. A mysterious doctor Salvator, a genius surgeon, calls him his son. Ichtiandr gets into trouble when an evil capitalist Pedro Zurita tries to exploit him due to his ability to breathe underwater; in the end, Ichtiandr has to leave the human society behind. Both the novel and the film end with a farewell to Ichtiandr, who swims away into the ocean to start a new life on an island in the Pacific, far away from the exploitative capitalist society.

The main question of the novel, mostly downplayed in the film, is what makes a human effectively "human" in a society. To support its bioethical argument, Amphibian Man introduces a horrific gallery of surgically modified creatures, inspired by H.G. Wells's The Island of Doctor Moreau (unfortunately, the film only shows a couple of perfectly normal monkeys, and leopard-dog hybrids are substituted with spectacular Great Danes). The difference is that, unlike the horrifying study of human cruelty by Wells, modified animals and even human-animal hybrids in Belyaev's book are all happy, healthy and enjoying themselves, playing together with human children in an idyllic, safely walled garden. It is implied that the operations enhanced their abilities and improved the quality of their lives, so similar operations could be performed on people to give them extraordinary abilities. Limitations and exploits are also discussed, to which I will return later.

The readers instantly fell in love with spectacular adventurousness of Amphibian Man, which could easily distract them from the novel ethical argumentation. It was first published in the illustrated geographic magazine Vokrug sveta (Around the World) - one of very few sources of information on remote and exotic foreign countries in the USSR. Its success resulted in $20 \%$ growth magazine subscription (Kravklis \& Levitin, 2009), and many reissues followed, as well as a much later film adaptation. Amphibian Man was adapted for the screen in 1961 to enormous success. Its theatrical release amounted to 65.5 million viewers in the USSR only (Kravklis \& Levitin, 2009). Anindita Banerjee connects this success to collective fascination with the launch of the Soviet space program (Banerjee, 2018). Due to its focus on ecological themes, it was one of the first "environmental science fiction" films in the USSR (Fedorov, 2017). There were other adaptations of Amphibian Man in the postSoviet period. A memorable musical for children The Sea Devil, produced by a Soviet and Russian film score composer Boris Savelyev, was released on vinyl by Melodia in 1991. Finally, a new Russian TV film adaptation of Amphibian Man was aired in 2004; it is considered artistically inferior (see Fedorov, 2017) and remains a TV obscurity. 
The 1961 adaptation of Amphibian Man still is a highly enjoyable classic of the Soviet cinema from the times of the political Thaw. Despite many cuts and some added propaganda, the original text had enough potential to be turned into a well received melodrama, almost identical to the main storyline of the much later similar film The Shape of Water (2017). A fair share of ideologically motivated changes has happened to the original text: most memorably, the film mentioned a nautical communist utopia of surgically modified 'fish people', but this topic was never explored visually. Unfortunately, recreation of tropical Argentina and its ocean life was far beyond the budget and creative constraints of the Soviet cinema. The film was shot in Crimea, with only a few murky underwater shots. Still, this was the first Soviet film with underwater scenes. Athletic bodies replaced colorful fishes in these genuinely immersive experiences that featured almost no exotic fauna but a lot of rather risky and, within the given constraints, beautifully staged diving.

Publication in a magazine first might have shaped the captivating style of the novel, which has never been fully translated to the screen. The serial format of an illustrated popular journal suggested extremely simple language and plentiful tropical scenes in this rather unevenly paced adventure. It can be argued that prolonged colorful expositions constituted immersive experiences for the majority of readers, who would not even own a color TV, let alone practice diving in tropical waters. Grandiose visions of the underwater world entered mass culture, and especially the post-Soviet visual culture, much later, first and foremost with the legacy of Jaques-Yves Cousteau adapted into Russian. Later Soviet geographic documentaries and publications in the illustrated journal Science and Life may provide an interesting case to a curious researcher of ocean worlds. More importantly, many parallels can be found between Cousteau's environmentalist message and the sheer sense of wonder projected by Amphibian Man, even more surprising as it was purely fantastic. It was the same 1962, the year when the film Amphibian Man was released, when Jaques-Yves Cousteau presented his own utopian concept of 'Homo aquaticus', a modified human who can live underwater (Crylen, 2018), almost as if Belyaev's prediction was finally coming true.

\section{IS AN AMPHIBIAN MAN A PERSON?}

The theory of recapitulation, developed in the 19 century and popularized by Ernst Haeckel, stated that every individual human, as well as many nonhuman animals, passes the same stages of development as their species have passed in their natural history. A human embryo resembles a fish at an earlier stage of their development, and shares certain features with a fish embryo, poetically speaking, it is "the obligatory underwater level" of its development. 


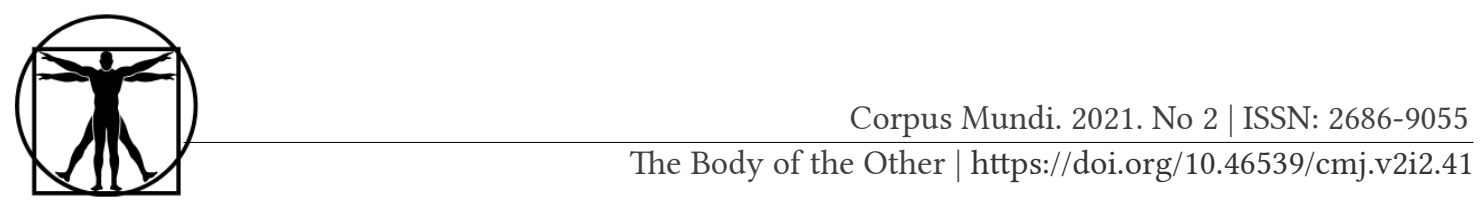

Amphibian Man specifically reminds its readers and viewers about "the biological law of Haeckel", according to which "A human embryo acquires four consequent gill folds on the twentieth day of its development" (Belyaev, 1993, p. 134). Later, Haeckel's theory appeared to be an oversimplification, but it still works as "the science" behind the main premise of the amphibian human. If a person has the potential to grow gills at the embryonic stage, then transplantation might be possible, although the immune response, which makes deliberate transplantation of organs impossible, was not yet fully understood at the time. We see the concept of physiological immunity challenged again in posthumanism, by pointing at its far-reaching semiotic implications (Haraway, 2015; Bennett, 2010).

The main ideological conflict of Amphibian Man as a novel is the symbolic argument between science and religion. It reaches its culmination in the scene of doctor Salvator's trial. Salvator is accused of blasphemy, animal cruelty and kidnapping, and he manages to lift two of these charges by defending himself. For the third charge, he receives a moderate and seemingly just two year sentence, to which he conforms. This scene, as well as the whole plot line involving religion, was removed from the screen adaptation.

The questions of bioethics raised by Belyaev, a graduate of a theological seminary and a lawyer by first occupation, are far from being resolved as of today. Anyway, it would be a stretch to interpret Amphibian Man as an early predecessor of the post-human ecological turn, which made such artifacts as The Shape of Water and ABZU possible. The religious point of view is presented by an antagonist, a sly disgusting Catholic bishop (expression of resentment towards representatives of any religion was a very strict rule in Soviet literature, which should adhere to orthodox Marxism-Leninism). For the bishop, the human body is sacred, and it should not be modified, for better or worse. In his own defence, Salvator says that he has made sick bodies healthy, and even made old bodies young again. There are also "female to male" creatures in the doctor's nightmarish Eden, although this topic is unfortunately not explored further.

The fictional dispute between science and religion is put to halt when the court rules Salvator guilty, and he receives his moderate punishment. Even though the court agrees that bodies can be modified for the benefit of their respective owners, Salvator still has repeatedly stepped out of the limits of patient's informed consent. He kidnapped a newborn child, and he has denied this child the right to be a part of the human society. These are crimes by today's standards, although, according to Belyaev, the reality was far more disturbing at the beginning of XX century.

Another bitter explanation for this light, purely symbolic sentence may come from the fact that the kidnapped child was indigenous. The most unset- 
tling part of the story was presented in the author's epilogue to the first version of the novel, which also contains a series of illustrations to the theory of recapitulation. According to Belyaev, doctor Salvator was a real person who went to a similar trial in Buenos Aires in 1926. He conducted surgical experiments on children of aboriginal people, "who praised him as a god" (Belyaev, 1928). Permission to do so, according to Belyaev, lies in the unlimited power of human knowledge.

Belyaev was wise enough to avoid the final ethical judgement. Never completely on the 'good' or 'bad' side, doctor Salvator in the book is consistently shown as exploitative and controlling to a pathological degree. His free healthcare for indigenous people is borderline exploitation, as they cannot afford professional medical care, and also, do not question the 'science' behind his deeds. As we can see from the romantic scenes, this controlling behavior is also present in Ichtiandr, which makes him more of a Salvator's son even if they are not biologically related. Salvator might even have arranged a marriage for Ichtiander, based on the ending of the book. The free-spirited underwater human does not have neither freedom nor agency on the firm land.

The fictional case of Ichtiander resembles real life borderline cases involving the rights of dolphins analyzed by Mary Midgley (Midgley, 2005). Amphibian Man presents a strong, even if fictional, argument that a person who lives the life of a dolphin may be not considered a human being, which leads to dire consequences. More specifically, it is Ichtiander's ability to breathe underwater which separates him from other humans and makes him 'less human' - a sea creature or a non-human animal that can be exploited for profit without acknowledging its rights. (Ichtiander is constantly referred to as a "toad" by the evil capitalist Pedro Zurita). The ability to live in the water becomes an excuse to withdraw legal protection against economic abuse and human cruelty.

Another, and even more bitter revelation is that legal personhood does not mean personal autonomy. Even if Salvator loves Ichtiander as a son, he still sees him as a public property to be used in scientific research. This is not far from treating him like a trained 'frog' to bring pearls, as the capitalist society does, but there is a hint in the text that in the communist society, Ichtiander should still belong "to the people" and not to himself. The dream for a better body comes with a social stigma, and even an improved body becomes de-humanized and operationalized as a tool in the society, be it a capitalist or a communist one. A new degree of freedom is required to break from the constraints of the social body. 


\section{“CAN YOU MEDITATE ON A SHARK?"}

As readers, we soon start noticing that Ichtiander spends considerable time in the 'exploratory mode', as it would be called in a video game. There are several sections completely dedicated to his underwater experiences, such as the chapter Ichtiander's Day. Together with the adventurous character, we explore the ocean and its inhabitants, ride the friendly dolphin and even fight giant octopuses. The latter battle scene seems to be added purely for the sake of its spectacularity, as it has very little to do with the plot. The stated motivation is that Ichtiander honestly has nothing else to do at the moment, apart from cutting through a few dozens of giant tentacles. After all, if we imagine Amphibian Man as a similarly paced and structured adventure video game, this battle will take the place of an appropriately difficult 'obligatory underwater level'.

How is water conceptualized in video games? Many volumes could be published on it, at the risk of drowning in the material, so we have to get by with a very brief overview. The list of water activities would include locations, levels and scenes from classical titles and series such as Assassin's Creed, World of Warcraft, The Legend of Zelda, - as it is commonly assumed, from most games developed by Nintendo. Generally, underwater constitutes the level where different rules apply. Virtual physics of in-game objects are cardinally changed or reversed, and the game space is re-structured in a different way (for example, gravity mirrored on the vertical axis). This reversal of the common ludic affordances makes such levels annoying and hard to beat, but neither engaging nor enchanting.

This particular way of thinking space and directions in video games may be relevant to the ways of thinking as such. Ben Woodard explores reverse directionality in his critique of "grounding", and he introduces the concept of 'ungrounding' (Woodard, 2013). He states that "the Earth has been used to ground thought instead of bending it" (Woodard, 2013, p. 3), and turns to speculative literature and even video games such as Half Life 2, Doom 3 and Deadspace in search of new un-grounding techniques. Although Woodard never mentions nautically themed games (there are not so many of them, after all), designing underwater levels can be seen as such exercise in "ungrounding".

Another major constraint of water levels is usually oxygen supply. "How long can I stay underwater?" is one of the first questions the professional game player Felix Kjellberg asks while playing $A B Z \hat{U}$ (Kjellberg, 2016). Even in games with aquatic protagonists, such as Ecco the Dolphin (1992), named among inspirations for $A B Z U$, the player character needs to get to the surface regularly to breathe air. Removal of this particular constraint was one of the goals in creating ABZU (PlayStation, 2016): its developer state that they wanted 
to create a game without any usual anxiety of drowning, and they consciously left out mechanics of health or resource mechanics such as air supply management.

In this way, $A B Z \hat{U}$ presents a counterargument to the common alienating way to construct marine worlds. Controls of the game can feel out of hand in the latter as well, but they are not particularly uncomfortable. Besides, the ocean is not an unknown terrain, but a formerly neglected home for the player character. The goal of its players is to revive and re-populate the underwater world with oceanic creatures, while learning more about these creatures, as well as themselves.

As the developers of $A B Z \hat{U}$ noticed (PlayStation, 2016), there is no strong tradition of underwater games to rely on. Some of the first sea exploration games are Everblue (2001) and Everblue 2 (2002): one of their innovations is that they present sea exploration from the first person perspective. Same as $A B Z \hat{U}$, they aimed specifically at recreation of scuba diving experience and exploration of the ocean. A later and more popular predecessor, the game Endless Ocean (2007), also developed by Arika and published by Nintendo, presented a third person perspective and a vast variety of sea creatures based on real species. It was followed by Endless Ocean 2: Adventures of the Deep in 2010, but neither of the games became a hit.

$A B Z \hat{U}$ takes ideas from these games several steps further, while introducing one important difference. This is not a realistic natural seascape: the setting is, just as in the case of Ichtiander, science fiction. Little drones accompany the player character and open the gates for them. Temple-like alternative spaces offer glimpses of buried ancient history as well as of advanced technological development, which might have caused degradation of some parts of this world. In their attempt to fix terrifying consequences of past technological catastrophes, players release ghosts of sea creatures back into the ocean to restore its former beauty. The message of the game is openly environmentalist, but it is delivered in a subtle and irresistably beautiful way.

The artistic statement behind $A B Z U \hat{U}$ has been regularly explained by its creators. Besides, this is not the first project of this kind: Matt Nava, the art director of $A B Z U$, has provided many gamers, as well as quite a few game studies scholars (see Flanagan and Nissenbaum, 2014; Chang, 2019 for most influential analysis), with two exemplary games that encourage caring relationships with the environment and the others: Flower (2009) and fourney (2012). It is agreed among most game critics that the project accomplishes its goals: it even temporarily made an internet personality like PewDiePie a slightly better person (and even speechless from time to time). 


\section{UNDERWATER AS QUEER ECOLOGY}

"You can live there, build houses! This is my dream to remain (to live) underwater - unreal, because it won't happen soon..." - these are the words of Galina Shurepova, the first female trainer of dolphins for military purposes in the USSR, from a documentary Galina Shurepova: the Amphibian Human. Amphibian Man was the first Soviet color film with underwater scenes, and she was a stunt woman for it - admittedly, risking her life on at least two occasions. If only she could get gills instead of lungs, now damaged by cancer, she would not hesitate for a minute. She wholeheartedly believed in underwater utopias of Belyaev and Cousteau. If a single person on Earth deserves to live in such underwater paradise, it should have been her - she preferred the company of dolphins to people anyway. Curiously, she also was a bit of a cyborg - her joints were replaced with transplants (Malechkin, 2007).

Documented Shuperova's relationship with dolphins fit into Haraway's later exploration of trans-human kinship (Haraway 2016). Similar relationships are also effortlessly performed in many fictional worlds, including the subjects of this study. Both Amphibian Man and $A B Z U$ feature intelligent dolphin companions of their post-human protagonists. In the case of $A B Z U$, the player can befriend any creature that is big and intelligent enough, starting from small fishes and sharks and ending with a blue whale. In Amphibian Man, the dolphin companion is an important character in the story. He has a name Leading - and Ichtiandr cares about him so much that he asks Salvator whether it is possible to introduce Leading to the inland world. In the book, Ichtiander is often depicted as a part of an enormous family of oceanic creatures, with whom he spends his merry days.

The posthuman project is envisioned, but not developed further in the original Amphibian Man, which attitude to scientific progress belongs to the ripe modernity of the beginning of the XX century. Ichtiandr is a humanshark hybrid, but sharks remain his enemies in the ocean. The young sharkman kills them without pity to save their prey - which eventually happens to be a damsel in distress. Similarly to many other stories about a savage coming of age, Ichtiander is no more satisfied with the company of dolphins. He needs a woman to prove himself as a man, so he saves the native Argentinian girl Guttiere and competes for her with another men, which soon gets him in trouble. This part of the narrative is somewhat conservative, although this patriarchal binary order is significantly loosened up by the unconventionally "unmanly" presentation of Ihtiander in the film, to which we will return later.

A similar fantastic ecology built almost a century later in $A B Z U \hat{U}$ has very different rules that are based on multitudes, not binaries. The player character is 
neither male nor female, although gamers tend to interpret them as a girl. This mysterious human-like figure does not look for any other companionship apart from see creatures. Another difference is that sharks are not enemies, but important spiritual animals in the game: they help the player character, and the player character helps them. It is possible to ride one of the many species of shark, including goblin sharks, leopard sharks, zebra sharks, whale sharks, and many more (the player learns their names in the game).

Appreciation of oceans and their dwellers is also of ancient Eurasian origin in this narrative: its writers refer to Sumerian mythology and the chthonic goddess Tiamat. (It can be argued that Sumerian mythology and literature influenced some of the key European narratives in the long run). This chtonic motive is supported in many ways across the game: the deeper players go, the more the underwater resembles the underworld. The approaching end of the underwater journey is marked by a whale cemetery and later a dimension inhabited by living dinosaurs.

Based on rejection of gender binaries, as well as the 'friend or foe' dichotomy, the technomythical world of $A B Z \hat{U}$ can be read as a 'queer ecology' (Mortimer-Sandilands et al., 2010). Queer ecologies emerge where 'natureculture' becomes productively non-binary, and this is also how the fictional world of the game appears to operate. Together with the protagonist, we make our way through the abandoned minefield and other remains of an obsolete technology with the best intentions to make the world 'whole' and 'clean' again, only to find out that there is no clear cut between "nature" and "technology" (who is saving whom from what?). In this relation, $A B Z \hat{U}$ is consistently posthuman. At the beginning of the game, the player character is naturally perceived as a clean slate for a new cycle of self-identification: it seems that they do not know where they came from, or who they are. Carried by the agency of the human player, the character learns everything they need to know from the environment, which suggests that they are in a beautiful place, surrounded by playful friends, some of whom just happen to be sharks. Whoever they are, the fluid character of $A B Z \hat{U}$ has to learn as much as possible, to make kin with the ocean, and to heal and restart its unique underwater world. There are no enemies to overcome: dangerous objects are remnants of what supposedly our own civilization has done to itself, and the most difficult mission is to accept it and to live through it. And even more: after we have completely identified with the player character, we are suddenly confronted with the painful realization that they (us) are not human. What was perceived as a gracefully moving body has always been only a swimsuit with dark matter underneath. It was never about "becoming one with nature", because the "self" has never been "natural". Still, heartfelt bonding and acceptance are still there, in this world, even after the irrepairable trauma its inhabitants have endured. 


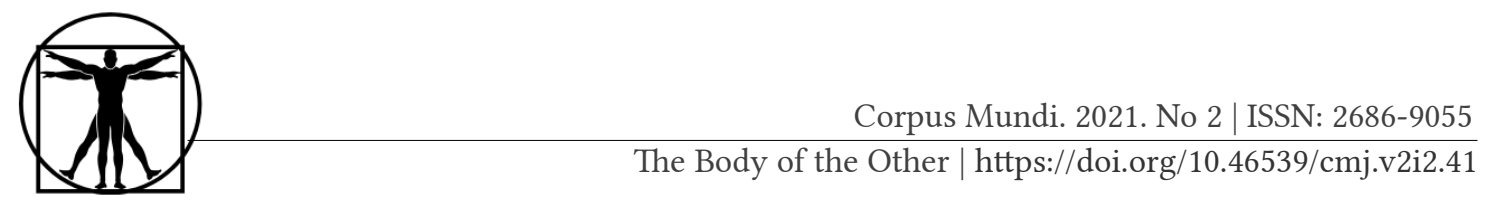

This surprising revelation of the "posthuman within" can be seen as an evolution of the "human within, monster outside" trope in the modernist age of the Amphibian Man. Ichtiandr looks like a human being when he is not wearing his suit and goggles, and yet, he is perceived as a monster even by those who have seen his real appearance. To explain this narrative discrepancy, Ichtiander's ability to breathe underwater can be framed as uncanny. As in Freud, the uncanny is always related to the familiar and homely. The uncanny by itself is not bad or negative, but it destroys the dichotomy between homely and strange and opens the gate to one's biggest fears, - in case of Ichtiandr, it may be interpreted as the fear of drowning, with its own long tradition of psychoanalytic interpretation. Anyway, this may be one of the ways to open up for the Other, or the Shadow, and ultimately the path to self-acceptance. Cyborgs are us, if we agree with Donna Haraway.

\section{“NEVER TRUST A MAN” (WITH A PERM): VULNERABLE MASCULINITY}

Despite embodying a non-binary condition (between humanhood and 'fishhood'), the Amphibian Man finds himself aligned with the binary, hierarchical order of things, where 'real men' make decisions for their 'frog-man' or 'shark-man' companion. This order endangers Ichtiandr's autonomy and even life. Even though Ichtiandr is biologically male and straight, which is supposed to give him certain privileges, he is also a cyborg and a part of a queer underwater ecology, which retracts his privileges and eventually makes him 'queer'. Ichtiandr looks rather androgynous, in the film adaptation from the 1961, although this was very much against the Soviet ideology even in the relatively liberal time of the Thaw. The cinematic Ichtiandr wears a glittery swimsuit covered with sequins underwater and a very short, feminine-looking romper at doctor Salvator's home. This look is complete with water-resistant nacreous aquamarine eyeliner, detectable in many close-ups even despite the low quality of preserved film copies. In such a daring way, a new kind of masculinity vulnerable masculinity was presented, and enthusiastically accepted by the female gaze: the young actor Vladimir Korenev enjoyed raving popularity among the female audience in the USSR in the 1960s.

This particular gaze gets the second choice in the film, and it is a different kind of a treat. Ichtiandr's archenemy, the stereotypical evil capitalist Pedro Zurita, is partially redeemed and made younger in the film (but also, he dies, while he and his business are flourishing in the finale of the original book). $\mathrm{He}$ is played by the extraordinarily handsome Michail Kozakov who represents a different challenge to the canon. His "exotic" Mediterranean appearance and peacock behavior were unseen in the Soviet cinema, which almost always 
preferred Nordic types as leads. This was yet another way to subvert dominant masculinity trends embodied in humble manners and athletic bodies of model Soviet men (Kon, 2002). Nevertheless, Pedro is also vulnerable and not 'masculine enough': the book and especially the film shows that, despite being a strong and dangerous person, almost a pirate stereotype, he is repeatedly humiliated by his mother who says he is "not a man" because he is not being firm enough, let alone aggressive, with Guttiere.

The romantic storyline remains most important in the narrative of both versions of Amphibian Man, even though it is presented in a contradictory and sometimes awkward way. Following the prevalent trope of mass culture, Ichtiandr falls in love with a girl whom he saves from the sea. She remains unconscious during their first encounter, and the romantic feelings of Ichtiandr are based on her looks and his saviour's complex, which is described with disarming sincerity in the book. This is just one of the many plot twists which have made the story so unashamedly melodramatic and simultaneously so appealing to the mass audience. Deprived from any previous education or experience in social relationships, Ichtiandr plainly stalks the girl, makes the connection and eventually wins her love, or, more likely, sympathy, with his naiveté, peculiar character and odd behaviour. The clichéd romance surprisingly resolves in a very ordinary way: in the end, Guttiere's long time friend Olsen rescues Ichtiandr's life, and Guttiere lets him go, not without regrets, but rather in the bittersweet mood of a summer romance. She later marries Olsen, a level-headed, hard-working Scandinavian who has already been "always there for her" for at least a year. Surprisingly, the much later film The Shape of Water (2016) presents an almost identical story with a different, even if similarly romantic, ending.

\section{QUEERNESS IS IN THE WATER}

Our last exhibit, The Shape of Water (2016), shares its director Guilliermo del Toro with the already mentioned Pacific Rim (2013). Guillermo's treatment of underwater world changes significantly when he moves from an established pop culture genre of 'kaiju' movies to 'auteur' cinema (emblematically, Pacific Rim already had episodic moments of sympathy and telepathic connection with underwater monsters). Here, the creative ambition of del Toro is to retell the story and re-imagine the main character of the classical vintage horror The Creature from the Black Lagoon (1954), but the result comes out even more similar to Amphibian Man.

The origins of the Creature can be traced back to America's own H. P. Lovecraft. In his highly influential horror story The Shadow over Innsmouth (1931), Lovecraft communicates almost hysterical fear in the face of 


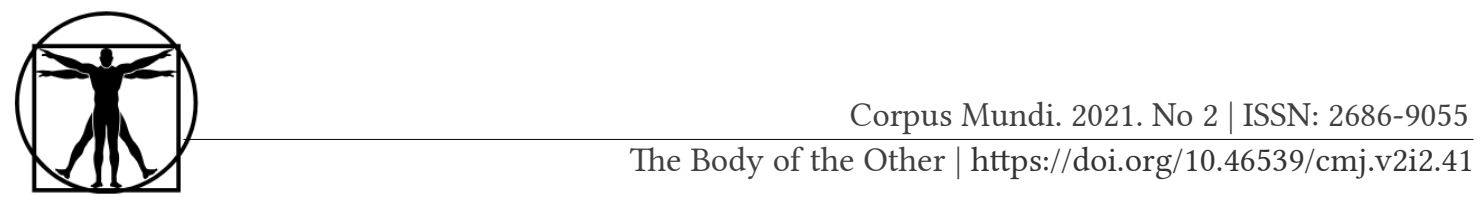

radical Otherness, breeding humans with sea monsters to blood-curdling results. In The Shape of Water, marriage to the sea is the act of love, not the one of violence: this is the story of affective acceptance of the Other, and this reversed blueprint coincidentally intersects with much of the Amphibian Man's plot structure. It does not matter for our goals whether del Toro stole the plot from the Soviet cinema or from any other story. The likeness and the interplay between these two films are even more impressive if no intentional plagiarism occurred.

The events in The Shape of Water supposedly take place in 1962 - the year when Amphibian Man was released in cinemas across the USSR and the Eastern bloc. Here I will list most striking formal and structural similarities between both films: the ability of the amphibian man to switch between two respiratory systems; these systems failing under harsh conditions; a big part of the prison escape plot; the main female character being an orphan from Latin America; accompaniment of the romantic line with distinctly Latin American folk music and, finally, general aesthetics of early sixties. Del Toro claims that he has never seen Amphibian Man, but The Creature from the Black Lagoon is black and white, not teal and neon. It is almost as if The Shape of Water was paying homage to Amphibian Man, recreating its nostalgic cityscapes and poetic retro-americana that the creators of the original film applied as "actual", even if naive, recreation of modern ordinary life in the West. These characteristic city views represented Soviet futurism in Amphibian Man, but they serve as signs of retrofuturism in The Shape of Water, resulting in an effect of somehow dislocated nostalgia.

Another, structural parallel can be drawn between Olsen, initially Gutierre's best friend, and Elisa's best gay friend Giles. Both of these characters are convinced by the heroine to save the amphibian man, they both agree for altruistic reasons, they both drive an ancient truck into the guarded facility to kidnap the prisoner, and they both take the star-crossed lovers to the ocean to release the amphibian man and to support the heroine when it is their time to part. The cardinal difference is that, in The Shape of Water, the heroine joins the amphibian man, who completes her by turning her into a fish-woman "cyborg". Still, in both examples, gender as such is not particularly fluid, although other topics and features of posthumanism are present. A man is a man (even when concealed underneath his natural or artificial swimsuit) and a woman is a woman, no matter how weak or strong. While being more or less successfully integrated into extended families of corals, dolphins, cats, native, black, gay or Swedish people, they ultimately seek each other in love. 


\section{COWBOYS AND INDIANS, HUMANS AND GODS}

How did two completely different films end up being so similar? In both cases, their artistic goals implied subverting particular gender tropes. In The Shape of Water, del Toro deconstructs the common trope of seaside horror: the woman is sacrificed to a horny monster while the man watches helplessly. As long as this trope is reverted, it accidentally spawns a queer ecology. Women are strong in this new world, despite having "no ranks", as they are constantly reminded. 'The sea devil' appears to be kind and humane, while the real monster is the power-thirsty man who has a fixation on his own masculinity. In contrast to the baton-swinging (but symbolically castrated - the 'monster' tore off his finger) colonel Strickland, the sea devil only reveals his masculinity in the moments of intimacy and trust (and, same as Ichtiandr, he also sparkles during his romantic moments).

Amphibian Man starts with rather conservative gender politics, preserved in the melodramatic "damsel in distress" trope, but its vivid characters overgrow it as soon as they are given the opportunity in the film adaptation. Initially, the book sets out to question the dichotomy between the human and the nonhuman animal. This message incidentally slides into utopian queerness of the film, which could only be shot as romantic instead of horrific. Soviet cinema stayed away from the horror genre for the most of its history, and the bestiary of doctor Salvador could not be embodied in it for financial and ideological limitations of its, still comparatively relaxed, period of Thaw. However, the scientific optimism and the instrumental 'technological' approach to the natural world, characteristic of early XX century's modern literature, has been mostly dismantled in the following century.

The difference between Amphibian Man and The Shape of Water in settling the question of humanhood can be best described by one of recurring dichotomies in early Haraway's work, where she counterposes biology as clinical practice versus biology as inscription (Haraway, 2015). In this dichotomy, Amphibian Man represents clinical practice (organ transplantation), and The Shape of Water represents inscription as mastery of human language. In the case of Ichtiandr, his (non-)humanity is derived from his physiology and shark gills. In The Shape of Water, the main difference between human and nonhuman is the ability to speak, and this is expressed by muteness of the heroine Elisa. Even the mute Elisa is "incomplete", in her own "words", precisely because she cannot speak, and her gills in the finale open in the place of scars from the injury that supposedly made her mute. In this way, she becomes the Subaltern who can, in fact, speak, thus dismantling the last hierarchy of oppression. This may be the same hierarchy that symbolically prevents Guttiere from following Ichtiandr into free waters of the Pacific Ocean. 


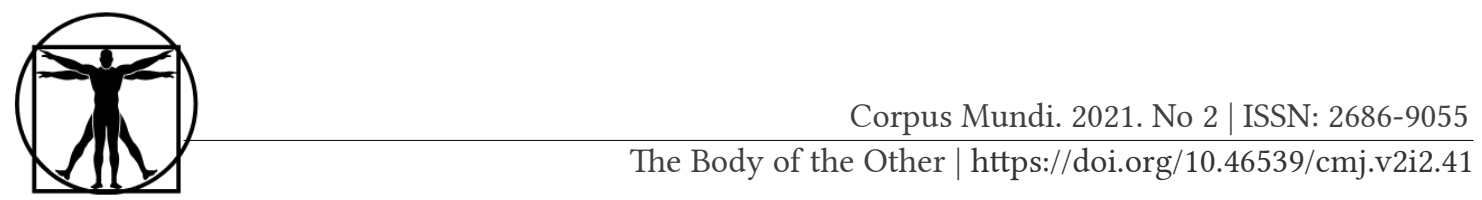

Is a 'sea devil' a person, and what excludes him from the humanity and subjects to inhumane treatment? In both cases, the human body is necessary, but not sufficient to be treated as a human. In The Shape of Water, the creature is not human because its body is different, but, based on the logic of colonel Strickland (the "real monster" of this story), - so are the bodies of many humans. Unknowingly revisiting the religious argument of Amphibian Man, he claims that the creature is not human, because humans are God-like, and "Lord looks like me", also suggesting that God is a man and not a woman. Still, this is a weak argument even for Strickland himself: later he admits that "the Soviets and the gooks" are also human, but this does not stop the Americans from killing them. We should not forget that the underwater creature is the actual God from the Amazon river in the fantasy world of the film. Christian parallels could be drawn, as well: this Amazonian God was acknowledged as such by poor people, he frequently performs miracles, and he resurrects in the end after being tortured and killed.

In both films (and the book), the question of humanity and personhood is explored once again in the form of more pronounced social critique. Another structural similarity from Amphibian Man miraculously reappears in The Shape of Water: the conflict between the "natives" and the "settlers". This early colonial motive was partially censored from the film, despite the liberties of the Thaw: in the book, the native American Balthazar, Pedro Zurita's companion, demonstrates his ancient dagger and reminds Zurita that it was used to "gut" Zurita's forefathers, Spanish conquistadors. In the film, the line is changed to "kill our enemies", which would sound out of context in this particular scene, be it not shot, by the way, in the multicultural and permanently contested Crimea. Eventually, both cases deliver the critique of the "less than human" status of indigenous people in South America, albeit more clearly pronounced in the book version of Amphibian Man.

\section{“THIS IS A LITTLE TOO DEEP”: CONCLUSION AND DISCUSSION}

Incomplete humanhood may be difficult to embrace from the viewpoint of the mind frame of Cartesian rationality (Midgley, 2005). Anxiety in the face of non-human may be the reason for relatively unsuccessful projects of immersive underwater utopias in media, and we can even speculate whether this was one of the reasons behind the fiery criticism against the aquatic human hypothesis. Not that this particular hypothesis seems grounded - it is just the emotional charge of objection against it that seems irrational (Foley \& Lahr, 2014).

As we can see, peaceful immersion into oceanic ecologies is strongly connected with the idea of leaving the 'human' behind, or transcending it, 
or generally opting out of 'humanhood' or personhood. Transcending the human by making ourselves a part of the water worlds may result in dehumanising in social environments; at least, this is what we see in fictional worlds. The "fish folk" is ostracized even when their quirks evolve to superabilities: Aquaman is considered a 'lame' superhero. Ironically, among the examples from science fiction which Donna Haraway brings for the cyborg theory, there is a story of a genetically modified amphibian woman who goes through surgical body modifications to be able to become a space pilot and she does it because she does not want to be amphibian any more (Haraway, 2015). Even though the contemporary philosophical agenda of dark ecologies offers a grand smorgasboard of beyond-human conceptualization, it also tends to follow the relatively Americanized way of approaching water ecologies, the one that can be traced back to the Lovecraftian anxiety in the face of the ultimately uncontrollable open waters and the creatures that inhabit them. Oceans are naturally too "hot and acid" even for Donna Haraway (Haraway, 2016), although the very point of environmentalism is to stop making them more so.

Speaking of body modifications, it seems as if many people would prefer bird wings to shark gills. Ichtiandr himself expresses his desire to have the wings of a giant petrel in the book. The ability to fly takes us to the great heights so we can see the world we live in from "the God's perspective", as game designers call it, - the advantageous viewpoint of a bird of prey (as deconstructed, for example, in the film Birdman (2014)). In the meantime, shark gills take us to a completely different world with different rules, where we can coexist with the scariest monsters without being scared. Unfortunately, this is not what general audiences dream about. In yet another, most recent pop culture narrative, we see a human with gills on Netflix, in the animated TV series Disenchantment. The brother of the main character Princess Tiabeanie is Bonnie Prince Derek, a son of a human king and a mermaid amphibian queen. He is a sad teenage emo boy who once wanted to kill himself because he felt lonely and rejected. In the episode Love's Slimy Embrace Derek comes to the shore to walk into the sea and drown, but then sadly realizes he has gills. This is the amphibian man of the early XXI century: he sees his gills as a burden, an extension of his creepiness, instead of using them as a key to a new, liberating world.

\section{ACKNOWLEDGEMENTS}

The author wishes to thank Péter Kristóf Makai and Sarah Lynne Bowman for their comments on the early draft of this paper. 


\section{References}

Alaimo, S. (2001). Discomforting Creatures: Monstrous Natures in Recent Films. In K. Armbruster \& K. R. Wallace (eds.) Beyond Nature Writing: Expanding the Boundaries of Ecocriticism (pp. 279-296). Charlottesville: University of Virginia Press.

Banerjee, A. (2018). A Possible Strangeness: Reading Russian Science Fiction on the Page and the Screen. In A. Banerjee (ed.) Russian Science Fiction Literature and Cinema: A Critical Reader (pp. viii-xv). Boston: Academic Studies Press.

Belyaev, A. (1928). Afterword to "Amphibian Man”. Around the World, 13, 200-202. (In Russian).

Belyaev, A. (1993). Amphibian Man. In Selected Works in Four Volumes: Amphibian Man. Jump into Abyss. Vol. 3 (pp. 5-156). Moscow: Young Guards. (In Russian).

Bennett, J. (2010). Vibrant Matter: A Political Ecology of Things. Durham: Duke University Press Books.

Chang, A.Y. (2019). Playing Nature: Ecology in Video Games. Minneapolis: University of Minnesota Press.

Chebotaryov, V., \& Kazansky, G. (1961). Amphibian Man. (film)

Crylen, J. (2018). Living in a World without Sun: Jacques Cousteau, Homo aquaticus, and the Dream of Dwelling Undersea. Fournal of Cinema and Media Studies, (58), 1-23. doi: 10.1353/cj.2018.0068

del Toro, G. (2017). The Shape of Water. (film)

Fedorov, A. (2017). The Western World in Soviet and Russian Cinema (1946-2016). Russian Education \& Society, (59), 319-464. doi: 10.1080/10609393.2017.1413880

Flanagan, M. \& Nissenbaum, H. (2014). Values at Play in Digital Games. Cambridge: MIT Press.

Foley, R. \& Lahr, M. M. (2014). The role of "the aquatic" in human evolution: Constraining the aquatic ape hypothesis. Evolutionary Anthropology: Issues, News, and Reviews, 23 (2), 56-59. doi: 10.1002/evan.21405

Haraway, D. (2015). Simians, Cyborgs, and Women: The Reinvention of Nature. London: Routledge.

Haraway, D. (2016). Staying with the trouble: making kin in the Chthulucene, Experimental futures: technological lives, scientific arts, anthropological voices. Durham: Duke University Press.

Kjellberg, F. (2016, August 1). Most Beautiful Game 2016!! (Abzu-Part 1) (video broadcast). PewDiePie. Retrieved from https://www.youtube.com/watch?v=RIfNvRWmOfk

Kon, I. (2002). Masculine Body as Erotic Object. In: On Masculi(Femini)ty. New Literary Review (pp. 43-78). Moscow. (In Russian).

Kravklis, N. \& Levitin, M. (2009). Three Lives of a Writer. Science and Life, 10, 126-132. (In Russian).

Lotman, J. (2001). Universe of the Mind: A Semiotic Theory of Culture. London: Bloomsbury Publishing. 
Malechkin, A. (2007). Galina Shurepova - "Amphibian Human” (documentary). Center-studio of national film "XXI century", Moscow. Retrieved from https://www.youtube.com/ watch?v=hfXyusEAwF0 (In Russian).

Midgley, M. (2005). Is a Dolphin a Person? In The Essential Mary Midgley (pp. 132-142). Oxford: Routledge.

Mortimer-Sandilands, C., \& Erickson, B. (2010). Queer Ecologies: Sex, Nature, Politics, Desire. Bloomington: Indiana University Press.

Nava, M., \& Balamut, B. (2016). Abzûu (video game).

PlayStation (2016). Abzu - PlayStation Underground Gameplay Video | PS4 (video broadcast). PlayStation. Retrieved from https://www.youtube.com/watch?v=lc6DCrODHnM

Schott, G. (2016). Violent Games: Rules, Realism and Effect. London: Bloomsbury Publishing.

Suvin, D. (1979). Metamorphoses of Science Fiction: On the Poetics and History of a Literary Genre. London: Yale University Press.

Woodard, B. (2013). On An Ungrounded Earth: Towards a New Geophilosophy. Santa Barbara: Punctum Books.

\section{Список литературы}

Alaimo, S. (2001). Discomforting Creatures: Monstrous Natures in Recent Films. In K. Armbruster \& K. R. Wallace (eds.) Beyond Nature Writing: Expanding the Boundaries of Ecocriticism (pp. 279-296). Charlottesville: University of Virginia Press.

Banerjee, A. (2018). A Possible Strangeness: Reading Russian Science Fiction on the Page and the Screen. In A. Banerjee (ed.) Russian Science Fiction Literature and Cinema: A Critical Reader (pp. viii-xv). Boston: Academic Studies Press.

Bennett, J. (2010). Vibrant Matter: A Political Ecology of Things. Durham: Duke University Press Books.

Chang, A.Y. (2019). Playing Nature: Ecology in Video Games. Minneapolis: University of Minnesota Press.

Crylen, J. (2018). Living in a World without Sun: Jacques Cousteau, Homo aquaticus, and the Dream of Dwelling Undersea. Journal of Cinema and Media Studies, (58), 1-23. doi: 10.1353/cj.2018.0068

Fedorov, A. (2017). The Western World in Soviet and Russian Cinema (1946-2016). Russian Education \& Society, (59), 319-464. doi: 10.1080/10609393.2017.1413880

Flanagan, M. \& Nissenbaum, H. (2014). Values at Play in Digital Games. Cambridge: MIT Press.

Foley, R. \& Lahr, M. M. (2014). The role of "the aquatic" in human evolution: Constraining the aquatic ape hypothesis. Evolutionary Anthropology: Issues, News, and Reviews, 23 (2), 56-59. doi: 10.1002/evan.21405

Haraway, D. (2015). Simians, Cyborgs, and Women: The Reinvention of Nature. London: Routledge.

Haraway, D. (2016). Staying with the trouble: making kin in the Chthulucene, Experimental futures: technological lives, scientific arts, anthropological voices. Durham: Duke University Press. 


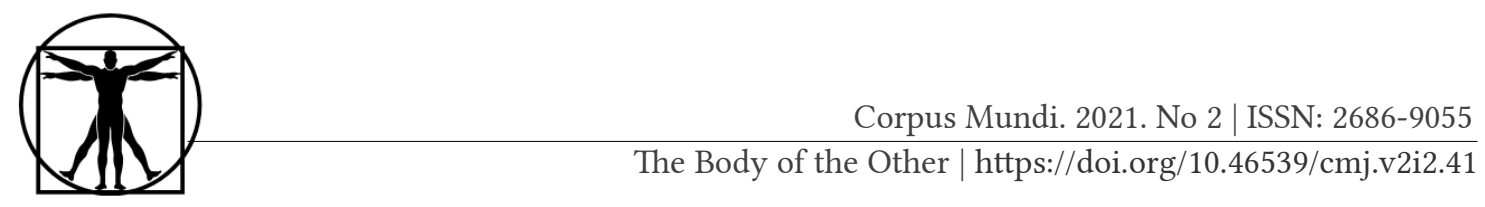

Kjellberg, F. (2016, August 1). Most Beautiful Game 2016!! (Abzu-Part 1) (видеопередача). PewDiePie. Retrieved from https://www.youtube.com/watch?v=RIfNvRWmOfk

Lotman, J. (2001). Universe of the Mind: A Semiotic Theory of Culture. London: Bloomsbury Publishing.

Midgley, M. (2005). Is a Dolphin a Person? In The Essential Mary Midgley, (pp. 132-142). Oxford: Routledge.

Mortimer-Sandilands, C., \& Erickson, B. (2010). Queer Ecologies: Sex, Nature, Politics, Desire. Bloomington: Indiana University Press.

Nava, M., \& Balamut, B. (2016). Abzûu (video game).

PlayStation (2016). Abzu - PlayStation Underground Gameplay Video | PS4 (видеопередача). PlayStation. Retrieved from https://www.youtube.com/watch?v=lc6DCrODHnM

Schott, G. (2016). Violent Games: Rules, Realism and Effect. London: Bloomsbury Publishing.

Suvin, D. (1979). Metamorphoses of Science Fiction: On the Poetics and History of a Literary Genre. London: Yale University Press.

Woodard, B. (2013). On An Ungrounded Earth: Towards a New Geophilosophy. Santa Barbara: Punctum Books.

Беляев, А. (1928). Послесловие к роману “Человек-амфибия”. Вокруг Света, (13), 200-202.

Беляев, А. (1993). Человек-амфибия. Избранные произведения в четырех томах: Человекамфибия. Прыжок в ничто. Том 3(5-156). Москва: Молодая гвардия.

дель Торо, Г. (2017). Форма воды (фильм).

Кон, И. (2002). Мужское тело как эротический объект. О муже(N)ственности (сс. 4378). Новое литературное обозрение.

Кравклис, Н., \& Левитин, М. (2009). Три жизни писателя. Наука и Жизнь (10), 126-132.

Малечкин, А. (2007). Галина Шурепова-"Человек-амфибия" (документальный фильм).

Центр-студия национального фильма "XXI век." Retrieved from https:// www.youtube.com/watch?v=hfXyusEAwF0

Чеботарев, В. \& Казанский, Г. (1961). Человек-амфибия (фильм). 